Fordham Law School

FLASH: The Fordham Law Archive of Scholarship and History

Faculty Scholarship

2020

The New Tax Legislative and Regulatory Process

Rebecca Kysar

Follow this and additional works at: https://ir.lawnet.fordham.edu/faculty_scholarship

Part of the Law Commons 


\title{
THE NEW TAX LEGISLATIVE AND REGULATORY PROCESS
}

\author{
Rebecca M. Kysar
}

This paper compares the enactment and implementation process for the 2017 Tax Cuts and Jobs Act (TCJA) to prior tax reform acts, as well as situates it within other developments in the legislative process more generally. It details how the 2017 enactment process solidifies reconciliation as the primary vehicle for the enactment of major tax measures, a trend nearly two decades in the making. The ambitious scope of the TCJA, as well as the rushed and partisan reconciliation process by which it was enacted, has led to ambiguities and instability in the legislation. These features have, in turn, posed an enormous implementation challenge for Treasury, which has led to some troubling results. Finally, reconciliation has set up the opportunity for Congress to engage in budget gimmicks in the future. This paper discusses these trends and proposes solutions to them.

Keywords: TCJA, tax legislative process, budget process, Byrd rule, reconciliation JEL Codes: H20, H60, D72

\section{INTRODUCTION}

ax lawmaking has never been elegant. Special interests, budget rules, and brute politics have long contorted the tax code, supplanting the traditional tax policy criteria of simplicity, equity, and efficiency with less pure aims. The 2017 Tax Cuts and Jobs Act (TCJA), the largest overhaul of the nation's tax laws since 1986, continues in this tradition, with its favored industries, revenue-forced trade-offs, and, at times, indefensible policy choices. ${ }^{1}$ The TCJA, however, is the culmination of a shift in the landscape. Reconciliation is now the primary vehicle for the enactment of major tax measures, a trend nearly two decades in the making. The 2017 process was notable in

\footnotetext{
Section 199A, for instance, has all three of these qualities. The passthrough deduction is only available to certain industries, expires in 2025 due to budget pressures, and has been characterized as "incoherent and unrationalized industrial policy, directing economic activity away from some market sectors and toward others, for no good reason and scarcely even an articulated bad one" (Shaviro, 2018, p. 49).
} 
that it was the first instance reconciliation was used to enact complex tax reform. As a fast track process, however, reconciliation was not up to the challenge.

The ambitious scope of the TCJA, as well as the rushed and partisan reconciliation process by which it was enacted, led to ambiguities and instability in the legislation. ${ }^{2}$ It has also posed an enormous implementation challenge for Treasury, which has led to some troubling results. Treasury has issued taxpayer-friendly regulations in contravention of the statute, benefiting multinational corporations and large businesses while further weakening an already flawed system.

Going forward, Congress should exercise careful oversight of Treasury's implementation of the tax laws so that it does not continually tilt toward the connected and well-funded. Creative solutions to this problem exist, such as rescission of the regulation, the appointment of an ombudsman to protect the public interest in rulemaking, making more transparent different avenues for participating in the rulemaking process, highlighting the budgetary costs of irresponsible rulemaking, requiring more detailed disclosure of tax liability, and simply delegating less through more precise statutory drafting. These changes can help further democratic legitimacy and protect revenues.

Reconciliation also has created opportunities for budget gimmicks. The rules of reconciliation forced a series of sunsets and sunrises to meet budget goals, causing tax cuts to expire or tax increases to spring into life at arbitrary points in time. If history is any guide, however, extending the temporary tax cuts of the TCJA will go unpaid for and the future tax increases will never go into effect.

Looking ahead, the trend of using reconciliation for tax reform may be short-lived. If the legislative filibuster falls, reconciliation will no longer be necessary to enact legislation on party lines. This would greatly diminish the role of the budget process, having implications for tax laws as well as the larger fiscal system. If that is the case, baking budget goals directly into tax legislation may be an alternative. In the meantime, there are ways to shore up the budget rules, such as stabilizing the budget baseline, which would diminish the effectiveness of budget gimmicks borne out of the reconciliation process.

This paper explores these trends and possibilities. Section II provides background on the reconciliation process and a general overview of the TCJA's enactment. Section III explores the implementation of the TCJA and recounts instances of Treasury overreach. For interested readers, this section provides detailed analysis of whether and where the new regulatory regime deviates from the statute. Mastering the details of Section III, however, is not necessary to follow the reminder of the paper. Section IV discusses what the tax legislative and regulatory process may hold in the near future and offers ideas for improvement.

\footnotetext{
2 Arguably, the rushed and partisan aspects of the process would have occurred with or without reconciliation. If reconciliation was not an option, Congress would likely be under pressure to eliminate the filibuster, as discussed in Section IV. Rushed and partisan legislation may then become the norm. Kysar (2013b, p. 2121) argued in prior work, however, that reconciliation has paved the way for the eradication of the legislative filibuster by steadily eroding the norms of the Senate.
} 


\section{RECONCILIATION AND THE ENACTMENT OF THE TCJA}

\section{A. Background on the Reconciliation Process}

The budget reconciliation process allows for limited debate and amendments, bypassing the Senate filibuster. Although it was originally envisioned in the Congressional Budget Act of 1974 as a modest tool that would align legislation with revenue and spending targets set forth in the budget resolution, ${ }^{3}$ it has since risen in importance. In the 1980s, as reconciliation legislation became more common, concern over abuse of the process began to rise. One of the original drafters of the Budget Act, West Virginia Senator Robert Byrd, led the charge toward safeguarding the process with the enactment of the "Byrd rule," which prevented the Senate from considering reconciliation legislation with "extraneous provisions."

Given the procedural advantage that reconciliation bestows, the minority party frequently invokes the Byrd rule to challenge provisions outside the reconciliation process. President Clinton seized upon reconciliation in the 1990s in order to enact significant policy changes. During this era, the Republican minority heavily relied upon the Byrd rule's protections (Kysar, 2013, pp. 2132-2133). One of the most notable effects of the Byrd rule occurred in 2001, when Senate Republicans wished to enact a historically large tax cut through reconciliation. Up until then, reconciliation had only been used to enact revenue-increasing or revenue-neutral legislation. Senate Democrats argued that the use of reconciliation for tax decreases violated the thrust of the original Budget Act, which "made it quite clear that the purpose of reconciliation was for deficit reduction" (Byrd, 2001, pp. S5651-S5652). The Republicans eventually won the procedural fight after the senate parliamentarian ruled that reconciliation could be used so long as the tax cuts were sunsetted. The sunsets allowed the legislation to comport with the Byrd rule's requirement that legislation not increase the deficit in any period beyond the budget window. ${ }^{5}$ Thus, the Economic Growth and Tax Relief Reconciliation Act of 2001 contained provisions that would return tax rates to their pre-2001 levels in 2011. Republicans would use the sunset tactic to enact future tax cuts through reconciliation, both in the Jobs Growth and Tax Relief Reconciliation Act of $2003^{6}$ and again in the TCJA. In addition to these tax acts, reconciliation was used by the majority party to enact the Tax Increase Prevention and Reconciliation Act of $2005,{ }^{7}$ as well as parts of the Affordable Care Act of $2010 .{ }^{8}$

\footnotetext{
See Congressional Budget Act of $1974 \S 310(\mathrm{c}), 88$ Stat. at 315.

4 Consolidated Omnibus Budget Reconciliation Act of 1985, Pub. L. No. 99-272, § 20,001, 100 Stat. 82, 390-91 (1986). The Byrd rule defines a provision as "extraneous" if it (A) does not produce a change in outlays or revenues; (B) produces an increase in outlays or decrease in revenues that does not follow the reconciliation instructions in the budget resolution; (C) is not in the jurisdiction of the committee that reported the provision; (D) produces changes in outlays or revenues that are merely incidental to the nonbudgetary components of the provision; (E) increases the deficit in any fiscal year after the period specified in the budget resolution (i.e., the "budget window"); or (F) recommends changes to Social Security. Id.

52 U.S.C. $\S 644(\mathrm{E})(2012)$.

6 Pub. L. 108-27, 117 Stat. 752.

Pub. L. 109-222.

8 Health Care and Education Reconciliation Act of 2010, Pub. L. 111-152 (2010).
} 


\section{B. The Implications of Reconciliation for the TCJA}

Reconciliation, thus, has been used to enact major tax acts since the early 2000s. The TCJA is notable, however, in that the tax provisions in these earlier reconciliation tax acts were far less ambitious in scope. It may therefore be more useful to compare the TCJA process with that of the Tax Reform Act of 1986, the last complex overhaul of the tax code.

The TCJA was enacted through the reconciliation in a matter of weeks without a single Democratic vote or even a hearing. In contrast, Congress considered the bipartisan 1986 reform over the course of three years. In the bipartisan 1986 reform, members from both sides of the aisle painstakingly put together the legislation - and only after Treasury produced a 262-page report on the contours of the new tax plan, the Ways and Means Committee heard testimony from more than 450 witnesses, and the Senate Finance Committee held 33 days of hearings (Leibenluft and Huang, 2017).

TCJA proponents would say that the reform process was years in the making, ever since the Republicans gained control of the House in January 2011, and that the bill was subject to regular order in that it was marked up in committee. But major, complex provisions of the bill, for instance, the base erosion and anti-abuse tax (BEAT), had not been vetted in open hearings at all. And those prior hearings did not have the benefit of the legislative text or even the bill's broad strokes. The choice to use reconciliation to enact the TCJA had several problematic implications, which derive from the fact that the process was being used to enact complex tax legislation (as opposed to simple rate cuts). I discuss these below.

\section{Importance of Estimates/Budget "Gimmicks"}

First, reconciliation heightens the role of the revenue estimates. The reconciliation instructions cap the overall cost of the legislation, and the Byrd rule disallows deficitreducing provisions in years outside the budget window. ${ }^{9}$ The budget rules lead to what Graetz (1995, p. 609) once called "paint by numbers" lawmaking. Revenue needs contour the final product, displacing the traditional tax policy criteria of simplicity, efficiency, and equity.

The costly lowering of the corporate rate presented a challenge for compliance with the Byrd rule. Several tactics were explored to cover the estimated $\$ 1.3$ trillion in revenue over the budget window period including a destination-based cash flow tax (DBCFT) that would bring in a great deal of revenue inside the budget window (Auerbach, 2017). The DBCFT met strong headwinds from industry representatives and was abandoned early in the process. Republicans also pursued a longer budget window of 20 or 30 years (as opposed to the traditional 10-year window) so that a sunset date for the corporate rate cut could be much further off, potentially overcoming the downsides of a temporary

9 Consolidated Omnibus Budget Reconciliation Act of 1985, Pub. L. No. 99-272, § 20,001, 100 Stat. 82, 390-91 (1986). 
cut (Kapur, 2017). In the end, however, Republicans also rejected this tactic, perhaps because a temporary corporate rate cut would have affected revenues for many years after the expiration date. ${ }^{10}$ To be in compliance with the Byrd rule, a corporate rate cut would have to be sunsetted well within the budget window period, regardless of the length of the window (Kysar, 2018b, pp. 61, 75).

During the 2017 process, Republican lawmakers also signaled they were considering changing the budget baseline to one of "current policy" in order to fit tax cuts within the parameters of reconciliation. The current official baseline is described as a "current law" baseline because it generally follows current law as written, with some exceptions (Kamin, 2015, pp. 143, 154-155). The parameters of a current policy baseline are less defined, but it was clear that the intention was to assume the continuation of several expiring tax provisions (better.gop, 2016, p. 16). This change would have rendered the $\$ 460$ billion costs associated with extension costless (Kamin and Kysar, 2017, p. 125).

Despite much discussion of the current policy baseline, Republicans ultimately adhered to the current law baseline in the budget resolution, perhaps because the senate parliamentarian took the position that any such baseline also had to apply to new tax cuts that expire, as well as old ones. Rhetoric surrounding the current policy baseline, however, heavily influenced the legislation. Key Republicans described the $\$ 1.5$ trillion tax cut figure agreed upon in the budget resolution as accommodating $\$ 500$ billion of revenue from a current policy baseline (in addition to an estimated $\$ 1$ trillion from dynamic growth) (Hanlon \& Rowell, 2017). Indeed, pivotal players, such as Senators Flake and Corker, made public statements that the current policy baseline influenced their vote in favor of the TCJA. ${ }^{11}$

There was also growing pressure to ditch reliance upon the independent congressional estimators - Joint Committee on Taxation (JCT) - and instead rely on nontraditional estimates, possibly from the Treasury Department. Attacks on the estimators began in conjunction with health care reform earlier in the year. During the first half of 2017, Republican criticism against the Congressional Budget Office (CBO) was so intense that eight former $\mathrm{CBO}$ directors wrote a letter to congressional leaders objecting to the attacks. ${ }^{12}$ Ultimately, the lawmakers respected the JCT's official score.

To summarize, the budget rules remained intact but some norms were destabilized in the process. The TCJA also revealed some fault lines such as the budget window,

${ }^{10}$ The JCT estimated that a three-year corporate rate cut would have produced nonnegligible revenue losses beyond the 10-year budget window period, seven years after the sunset date. Letter from Thomas A. Barthold, Chief of Staff of Joint Committee on Taxation, to Paul D. Ryan, Speaker of the House of Representatives (April 25, 2017), at http://www.politico.com/f/ ?id=0000015b-a645-d0b0-afdb-b7c7e71d0001. This is because companies would shift profits to years in which the lower rate was in effect (Kysar, 2018b, p. 75).

${ }^{11}$ Hanlon and Rowell (2017) referencing statements by Senators Flake and Corker that rely upon a current policy baseline in justifying their support for the tax bill, revenue losses notwithstanding.

${ }^{12}$ Letter from Former CBO Directors on the Importance of CBO's Role in the Legislative Process to Paul Ryan, Speaker of the House, et al. (July 21, 2017), https://medium.com/@douglas.elmendorf/letter-fromformer-cbo-directors-on-the-importance-of-cbos-role-in-thelegislative-process-278863b7e1c6. 
the baselines, and the independence of the estimators. Under a different scenario, a longer budget window could have served the goal of longer sunsets and, thus, may be deployed in the future. Although Republicans adhered to the current law baseline, they invoked an alternative baseline to justify costlier legislation. Similarly, at the outset, they relied upon dynamic growth to rationalize the size of the tax cuts, although the official dynamic estimates would later prove to be unhelpful to their cause. ${ }^{13}$ Although Republicans adhered to the JCT estimates, they came close to discarding them.

Ultimately, Republicans relied on tried and true mechanisms of fitting large tax cuts within reconciliation. Many of the TCJA's provisions, especially on the individual side, sunset in 2025 in order to keep the costs within reconciliation's parameters. ${ }^{14}$ Additionally, tax increases that do not spring to life until future years, in particular with regard to the international provisions, aim to bring in revenue later. ${ }^{15}$ The sunrise provisions will face a lot of opposition from industry and may never go into effect. For example, the excise tax on high-cost employer medical plans was a sunrise provision and has been delayed twice (Van de Water, 2019).

The sunsets that were used in the bill to meet the requirements of reconciliation will create the need for new legislation in the next few years. The Bush tax cuts were largely extended without being paid for by creating an exemption from the pay-go rules, which require offsets for tax cuts. ${ }^{16}$ The same tactic may be pursued to extend the TCJA's temporary provisions. The rhetoric of the current policy baseline could obscure the costs of renewing the popular provisions in the TCJA, which in turn may pave the way for permanency of the new expiring tax cuts with an exemption from pay-go rules.

Moreover, the temporary nature of the provisions is, at times, antithetical to the policies at which they are aimed. The TCJA, for instance, allows companies to expense or deduct capital expenses in full in the year in which they were incurred, as opposed to having to depreciate the cost over a number of years. Expensing is designed to increase capital investment, thereby growing the economy, but temporary expensing mutes these effects. ${ }^{17}$

${ }^{13}$ The parliamentarian reportedly disallowed using dynamic scoring for reconciliation (Clifton, 2017). JCT's official dynamic score of the conference bill projected an increase of deficits by $\$ 1.1$ trillion, a modest improvement over the conventional score of $\$ 1.5$ trillion over the same budget window period. Joint Committee on Taxation, Macroeconomic Analysis of the Conference Agreement for H.R. 1, The "Tax Cuts and Jobs Act," JCX-69-17, https://www.jct.gov/publications.html?func=startdown\&id=5055.

${ }^{14}$ See, for example, 26 U.S.C. $§ 1(j)$ (sunsetting the rate tables in 2025). The sunsets occurred in 2025, rather than the end of the budget window, because this kept the costs within the $\$ 1.5$ trillion figure set out in the budget resolution. The Byrd rule requires that legislation comply with the reconciliation instructions and that reconciliation legislation does not increase deficits beyond the budget window period.

${ }^{15}$ See, for example, 26 U.S.C. $\$ 250$ (reducing the deduction for GILTI after 2025).

${ }^{16}$ American Taxpayer Relief Act of 2012, Pub. L. No. 112-240, § 911, 126 Stat. 2313 (2012) (ordering that the Act's budgetary effects be ignored for pay-go purposes).

${ }^{17}$ The Tax Foundation estimated that permanent expensing would grow the economy by 1.6 percent after a decade but that temporary expensing would do so only by 0.18 percent (Pomerleau, 2017). 
In many senses, then, reconciliation gave us the worst of both worlds. The destabilizing of budget norms paved the way for Republicans to agree upon an inflated number in the reconciliation instructions, which functions as a ceiling and a floor for tax cuts (Aprill and Hemel, 2018, pp. 99, 129). That number forced a patchwork of temporary and delayed provisions that increase uncertainty for taxpayers and hamper economic growth without actually producing fiscal responsibility.

\section{Partisan Legislation and Instability}

Tax reform should be somewhat durable if it is going to create proper investment incentives. Reconciliation, however, tends to produce temporary legislation, not only because of the revenue-forced sunsets but also because of the fact that it is a partisan process. One consequence to circumventing the Senate filibuster through reconciliation is the production of immoderate legislation, which has a greater likelihood of being altered by a later majority.

The argument that a supermajority rule leads to more moderate decision-making has been made in the judicial nominee context. Due to the need to appease the "pivotal senator," or the senator whose support the president needs to secure a supermajority vote, rather than the median, or the $51^{\text {st }}$ senator, supermajority rules lead to an agreement closer to the median senator, that is, to a more moderate agreement (McGinnis and Rappaport, 2005, pp. 257, 261-281). This analysis can extend to the legislative context, where supermajority rules produce laws that are more closely aligned with the ideology of the median senator.

Bipartisan buy-in ensures that the minority will not act to quickly undo the legislation when it regains Congress. Using reconciliation, however, meant that Republicans did not need to secure even one Democratic vote during the TCJA process. This was in contrast to past tax overhauls that involved support from the minority party. The past three tax reform acts, for instance, occurred during times of divided government, outside of the reconciliation process. ${ }^{18}$ Even the 2001 Bush tax cuts were supported by 12 Democratic senators. A bipartisan process would have produced more moderate, and hence more stable, policy. Instead of a 21 percent corporate rate cut that is likely to be undone if Democrats regain control of Congress, Democrats and Republicans likely would have enacted a more modest rate cut with staying power. The many sunset provisions in the TCJA will themselves further destabilize the legislation going forward.

The partisan aspect of the TCJA process also illustrated another shortcoming of using reconciliation for tax reform. When one party is supporting a policy, it is difficult to produce the requisite level of revenues. This is because no one party wants to be blamed for hardships caused by increased taxes and decreased spending, which are often more salient to voters than the abstract goal of deficit reduction. Bipartisanship

\footnotetext{
18 " $[\mathrm{I}] \mathrm{t}$ may not be coincidental that the three tax acts that have garnered the 'tax reform' label have all occurred during periods of divided government when bipartisan compromise was necessary" (Yin, 2006, pp. 977, 1031).
} 
is often thought of as a necessary ingredient to tax reform so that one party alone does not get blamed for taking away special tax benefits or otherwise raising taxes on one industry or another. If the parties together took on the goal of fiscal responsibility and reducing special interest provisions, then difficult choices to effectuate that goal would be more politically palatable. The TCJA, instead, is estimated to produce a revenue loss of $\$ 1.9$ trillion over 10 years, significant stimulation to an economy that was arguably near full capacity. On net, it also actually increased the number of tax expenditures in the Code (Bellafiore, 2018).

\section{Diminishment of Tax Institutions}

Reconciliation also tends to sideline the tax institutions when it comes to policy formation as compared to their role in earlier eras. The need to come up with reconciliation instructions in the budget resolution means that the party leaders heavily influence the bill at the outset. This reduces the policymaking role of Treasury and the tax writing committees. Although the estimating power of the JCT is essential to the reconciliation process, this serves to weaken its role in policy formation by channeling its resources to the estimating function. The expertise that the tax institutions could bring to bear on the legislation is greatly diminished through the reconciliation process.

\section{Mistakes and Ambiguities}

There are inevitable mistakes and ambiguities in tax legislation when the process is cut short. As discussed above, the Tax Reform Act of 1986 evolved over the course of two years, and prior tax reform efforts had similar or longer time frames for debate, consideration, and drafting. ${ }^{19}$ In contrast, the TCJA was enacted in a matter of weeks. Tax law is a notoriously complex area of the law with many interconnected parts, and the rushed drafting of the TCJA produced a number of errors and ambiguities, sometimes with billions of dollars at stake.

One justification for a rushed process is that it gives interest groups less time to work their magic on politicians. The TCJA, in some respects, performed well in this regard. It does not contain the notorious "rifle shot" provisions, which benefit single taxpayers or industries, that riddled the Tax Reform Act of 1986. Nonetheless, it would be a mistake to think that the legislation does not respond generously to business interests. International base broadening provisions were the quid pro quo for the low corporate tax rate. Unfortunately, the base broadeners failed to reduce meaningfully profit shift-

\footnotetext{
${ }^{19}$ Birnbaum (1988) chronicling the 1986 tax overhaul. The Bankruptcy Tax Act of 1980, in which the tax treatment of bankrupt taxpayers was clarified, took nearly four years after "extensive debate and comment" (Handler, 1987, pp. 1259, 1262-1263). The Subchapter S Revision Act of 1982, which eliminated the double taxation of closely held corporations on an elective basis, was enacted after two and a half years of consideration. Id.
} 
ing, making for a costly trade. ${ }^{20}$ The new 21 percent corporate tax rate loses significant revenue. ${ }^{21}$ Moreover, it is an overly generous reduction of the overall tax burden on corporate income when one takes into account that many institutional shareholders are tax-exempt (thus eliminating the shareholder burden of the corporate double tax) and that expensing currently eliminates taxation on the normal return on capital. TCJA proponents cited competitiveness concerns as the reason for lowering the rate. Prior to the TCJA, however, there was little actual evidence that U.S. corporations were competitively disadvantaged (Clausing, 2020a).

One question is whether courts will take into account the rushed process by which the TCJA was enacted in considering its error-ridden and ambiguous provisions and Treasury's implementation of it. Whether, for instance, they will be forgiving in interpreting the text. There is some precedent for this. In King v. Burwell, the Court considered the question of whether a sloppily drafted tax provision in the ACA, providing for health insurance subsidies purchased through the "Exchange[s] established by the State" included insurance through state and federal exchanges or just the former. The Court ultimately construed the phrase at issue liberally to encompass federal exchanges. In so doing, the Court recognized the streamlined process by which the Act was enacted, reasoning that reconciliation took away "care and deliberation that one might expect of such significant legislation" resulting in "inartful drafting."22

${ }^{20}$ The TCJA adopted a 10.5 percent minimum tax on certain foreign income of foreign subsidiaries to combat incentives for multinational corporations to shift their profits offshore under the TCJA's new quasi-territorial regime. The design of the minimum tax, however, largely preserves profit shifting incentives as compared to pre-TCJA law (Kysar, 2018a). Specifically, the minimum tax currently allows multinationals to blend their tax credits from high and low tax countries, thereby incentivizing profit shifting toward both types of jurisdictions. Applying the minimum tax on a per-country basis would foreclose the existing ability of corporate taxpayers to offset their U.S. tax liability of foreign income in low-tax countries with foreign tax credits on income from high-tax countries. Clausing (2020b) estimates that a per-country minimum tax reduces haven profits by 23 to 31 percent as compared to 12 to 16 percent under a global minimum tax. Additionally, the generous GILTI deduction taxes foreign income at half the rate of domestic income, encouraging profit shifting. Decreasing the effective rate differential between the two types of income would decrease incentives to shift profits. Prior minimum tax proposals set the minimum tax rate at 67 percent of the regular corporate rate. The White House and Department of the Treasury, The President's Framework for Business Tax Reform: An Update 4 (2016), https://www.treasury.gov/resource-center/tax-policy/Documents/The-Presidents-Framework-forBusiness-Tax-Reform-An-Update-04-04-2016.pdf. Finally, the 10 percent exempt deemed return on assets is arbitrary and too high given that the average risk-free rate of return has been much lower. This encourages the shifting of tangible assets, such as manufacturing assets, from the United States to offshore locations in order to obtain the benefit of the exemption. Instead, the exempt return could be eliminated, or the rate could be pegged to a dynamically adjusting market interest rate or lowered to something closer to the risk-free return on Treasury yields. Leaving aside the one-time transition tax, the JCT's score for the international provisions in the TCJA indicated a $\$ 14$ billion revenue loss for the 10 years subsequent to enactment. Estimated Budget Effects of the Conference Agreement for H.R. 1, The "Tax Cuts and Jobs Act," JCX-67-17 (December 18, 2017), https://www.jct.gov/publications.html?func $=$ startdown\&id $=5053$.

${ }^{21}$ Note that a corporate rate increase to 28 percent would raise approximately $\$ 730$ billion over 10 years (Batchelder and Kamin, 2019).

${ }^{22}$ King v. Burwell, 135 S. Ct. 2480 (2015). For discussion of this issue, see Kysar (2021). 
King v. Burwell is also notable for a different reason. Surprisingly, the Court refused to follow Chevron to defer to the Internal Revenue Service's (IRS's) interpretation, which comported with the Court's ultimate holding. The Court held that Chevron did not apply because there was no implicit delegation from Congress to the IRS when there is a question of "economic and political significance." ${ }^{23}$ This brings us to the next part of the paper, which focuses on Treasury's implementation of the TCJA.

\section{TREASURY'S IMPLEMENTATION OF THE TCJA}

The ambitious scope of the TCJA, as well as the rushed process in which it was enacted, has posed an enormous challenge for Treasury, which is charged with interpreting and implementing the legislation. Several dynamics weigh this process in favor of sophisticated taxpayers, particularly those that have resources to influence the regulatory process. In several cases, Treasury has weakened the anti-base erosion features in the TCJA in the face of intense lobbying for business interests. Troublingly, many of these regulatory giveaways have no statutory basis. ${ }^{24}$

Recently, the $\mathrm{CBO}$ made a downward technical adjustment of $\$ 110$ billion, largely attributed to the law's international provisions, including from Treasury's regulations and new financial data (CBO, 2020b, pp. 73-74) ${ }^{25}$ Although the CBO does not provide further information on which international regulations might be contributing to this downward adjustment in revenue, below, I discuss some areas where the Treasury regulations have been overly generous to corporations, perhaps in ways that the scorekeepers did not anticipate in their initial estimate of the law.

\section{A. The TCJA Regulatory Process}

Given the complexity of the new TCJA regime, its truncated legislative process was bound to create problems. Treasury was left in the position of interpreting and implementing hastily drafted provisions that interacted with old law in sometimes unforeseen ways. This opened the door for taxpayers with resources to exercise significant influence over the regulatory process, which lacks safeguards against such abuse. Even when career staff at Treasury protested proposed regulatory rules on the basis they lacked statutory authority, political appointees within Treasury reportedly dismissed their concerns (Drucker and Tankersley, 2019). This illustrates that institutional safeguards cannot always withstand political pressures to pursue policy objectives. ${ }^{26}$

${ }^{23}$ King v. Burwell, 135 S. Ct. 2480 (2015).

${ }^{24}$ These developments were not unforeseen. Prior to the TCJA's enactment, academics and other commentators warned of their possibilities given the inherent design flaws in the legislation, the rushed manner in which it was passed, and the foreseeable dynamics in the regulatory process. See, for example, Kamin et al. (2017).

${ }^{25}$ See also CBO (2020a) reiterating that the revisions reflected, in part, implementation of the law, "including regulations announced by the Internal Revenue Service over the past year."

${ }^{26}$ Although Treasury may change course in the future upon an administration change, there are political costs to doing so given the reliance interests on the initial interpretations. 
In order to protect the administrative state against democratic deficiencies, administrative law mandates that an agency must provide notice of proposed regulations and grant the public an opportunity to comment on them. Yet nothing prevents sophisticated actors from rushing directly to agency officials in hopes of catching their ear prior to this "notice and comment" period. These prenotice communications, which are not transparent to the public, benefit from first-mover advantage (Oei and Osofsky, 2019, p. 209). ${ }^{27}$ If a special interest can influence Treasury toward a favorable interpretation initially, it is likely that interpretation carries over into the final regulations (Oei and Osofsky, 2019).

In the case of the TCJA, sophisticated parties clearly benefitted from these nontransparent first-mover advantages. Before the ink was dry on the TCJA, business actors and representatives swarmed Treasury to advocate for their interests (Oei and Osofsky, 2019). Treasury officials reportedly met with lobbyists for companies and industries roughly 10 times a week (Oei and Osofsky, 2019). At crucial turns, Treasury acquiesced to their demands, sometimes in contravention of clear statutory language. Notable examples of this can be found throughout the regulations implementing the new international tax provisions, Section 199A, and the opportunity zone incentives.

These first-mover advantages compound the greater participation that sophisticated parties already have in the formal notice and comment period. In the tax context, industry actors tend to dominate the formal notice and comment process. This is because they have resources to deploy and because they stand to gain more from a favorable interpretation than any particular member of the public stands to lose from it. Furthermore, members of the public who are disadvantaged by Treasury giveaways to sophisticated taxpayers likely do not have standing to challenge such giveaways under current law. ${ }^{28}$ Tax practitioners and bar associations are further constrained by client interests from making anti-taxpayer comments (Shay, 2019, pp. 1129, 1145). These resource and incentive differentials generally result in few, if any, public-oriented comments in the regulatory process.

The phenomena of delivering regulatory benefits to taxpayers without clear statutory authority is an old problem of bipartisan pedigree. During the financial crisis of 2008, for instance, the Bush-era IRS issued guidance that allowed multi-billion-dollar relief

\footnotetext{
${ }^{27}$ Importantly, courts do not require transparency of prenotice activity. Some of this activity can be reconstructed after the fact due to press reports, Treasury's own references to it in its notice of proposed rulemaking, and information released related to Office of Information and Regulatory Affairs (OIRA)/Office of Management and Budget review. Id.

${ }^{28}$ See Simon v. E. Ky. Welfare Rights Org., 426 U.S. 26, 46 (1976) (Stewart, J., concurring) (stating that he could not "imagine a case, at least outside the First Amendment area, where a person whose own tax liability was not affected ever could have standing to litigate the federal tax liability of someone else"); Allen v. Wright, 468 U.S. 737, 740 (1984) (denying taxpayer standing for a challenge to the tax exemption of segregated schools); DaimerChrysler Corp v. Cuno, 547 U.S. 332, 340-46 (2006) (denying standing for third party challenges to state and local tax breaks); Hein v. Freedom From Religion Foundation, 551 U.S. 587 (2007) (denying taxpayer standing to challenge favorable administrative decisions, contrary to the statute, under First Amendment grounds). For a discussion of these issues, see Hemel (2017, p. 633), Sugin (2016, p. 617), and Zelenak (2012, pp. 829-855).
} 
from Section 382's loss limitations on acquired companies. ${ }^{29}$ The guidance was tailored purportedly to facilitate the acquisition of Wachovia by Wells Fargo. The Obama-era IRS continued this approach to extend similar benefits to the Treasury Department upon a sale of its shares of General Motors, again without statutory support. ${ }^{30}$

The rushed and unorthodox manner in which Congress now legislates, however, creates more ambiguous and imperfect tax provisions than in the past (Kysar, 2013, pp. 2121, 2018, 61; Oei and Osofsky, 2019). In this new legislative environment, Treasury and the IRS will be under tremendous strain to provide guidance quickly to taxpayers. Exploring ways in which Congress can help protect against agency capture and democratic deficiencies is more pressing than ever.

The below examples are a nonexhaustive list of TCJA regulations that go beyond the text of the statute.

\section{B. Examples of Treasury Overreach from the International Provisions}

\section{GILTI}

\section{a. THE HIGH-TAX EXCEPTION ELECTION}

The new 10.5 percent minimum tax on global intangible low-taxed income (GILTI) on certain foreign source income allows corporations foreign tax credits for 80 percent of foreign income taxes. This generally means that no GILTI liability ensues if a taxpayer pays a tax rate of at least 13.125 percent abroad. ${ }^{31}$

Shortly after GILTI was enacted, however, tax experts quickly noticed that GILTI liability may occur even when the foreign tax rate exceeds 13.125 percent (Sullivan, 2018 , p. 845). This is because, in determining the foreign tax credits, expense allocation rules require that some expenses that generally have worldwide benefits (such as research, interest, and overhead) have to be allocated, in part, to reduce foreign source income (and, hence, their foreign tax credits) even though they are incurred in the United States. These rules, thus, strive to better match income with economic reality and to prevent taxpayers from improperly inflating their foreign source income to reduce their tax liability. In circumstances where such expenses are allocated to foreign source income, taxpayers may have GILTI tax liability even when they are paying a foreign effective tax rate exceeding 13.125 percent.

Taxpayers who were unhappy with this result lobbied Treasury to implement a hightax exception that would eliminate GILTI tax liability whenever a taxpayer paid at least a 13.125 percent effective tax rate. In proposed regulations, Treasury acquiesced to their demands, specifically citing comments they had received from taxpayers in their decision to do so. For reasons explained below, however, Treasury granted the high tax

\footnotetext{
${ }^{29}$ IRS Notice 2008-83, 2008-2 C.B. 905.

${ }^{30}$ IRS Notice 2010-2, 2010-1 C.B. 251.

${ }^{31}$ Eighty percent of 13.125 percent equals the GILTI rate of 10.5 percent, thereby completely offsetting GILTI liability.
} 
exception only for those taxpayers paying at least an 18.9 percent rate abroad who elect into the exception. ${ }^{32}$ In doing so, Treasury exceeded its statutory authority.

The route that Treasury used to justify the high-tax exception is through the subpart F regime, which requires current inclusion of generally passive income at the full 21 percent corporate rate, as opposed to the GILTI rate of 10.5 percent. Subpart F has a high-tax exception for certain categories of Subpart F income (specifically "foreign base company" income and "insurance company" income) taxed at a foreign rate that is more than 90 percent of the regular 21 percent corporate rate (or 18.9 percent). The new GILTI statutory provisions state that income excluded from Subpart F by reason of this preexisting high-tax exception (in addition to subpart $\mathrm{F}$ income generally) is also excluded from GILTI. ${ }^{33}$ Treasury seized upon this cross-reference as a means to provide corporate taxpayers with what they wanted. Unfortunately, the language of the cross-reference cannot bear the meaning given to it by Treasury.

Specifically, the GILTI cross-reference carves out from the definition of income subject to GILTI:

[A]ny gross income excluded from the foreign base company income (as defined in section 954) and the insurance income (as defined in section 953) of such corporation by reason of section 954(b)(4) [the high-tax exception in subpart F]..$^{34}$

The clear reading of this language - indeed the only reasonable reading of it excludes from GILTI only that income that would otherwise be foreign base company or insurance income but for the high-tax exception in subpart F. In the regulations, however, Treasury has twisted the words of the statute to exclude any income, be it within the enumerated categories or not, so long as the income is subject to an 18.9 percent or higher rate abroad. Effectively, Treasury's strained reading adds the following nonsensical language to the statute:

[A]ny gross income excluded from the foreign base company income (as defined in section 954) and the insurance income (as defined in section 953) of such corporation by reason of section 954(b)(4) as well as any income that would have been excluded by reason of that subsection but for the fact that it did not constitute foreign base company income and insurance income.

Treasury justified its statutory reading by noting in the Preamble to the regulations that there is nothing in Section 954(b)(4) that restricts its application to income that "first qualifies as" foreign base company income or insurance income but, instead, that sub-

\footnotetext{
${ }^{32}$ Guidance under Section 958 (Rules for Determining Stock Ownership) and Section 951 A (Global Intangible Low-Taxed Income), 84 Fed. Reg. 29114 (June 21, 2019) [hereinafter Proposed GILTI Regulations].

${ }_{33} 26$ U.S.C. $\S 951 \mathrm{~A}(\mathrm{c})(2)(\mathrm{A})(\mathrm{i})(\mathrm{III})(2018)$.

${ }^{34}$ Id.
} 
section applies to "any item of income received by a controlled foreign corporation." 35 The language Treasury quotes from the statute reads in full: "foreign base company income and insurance income shall not include any item of income received by a controlled foreign corporation" that is taxed at the requisite high rate. No school of statutory interpretation would construe this language to include income other than those two enumerated categories. As Shay $(2019$, p. 1139) has succinctly reasoned, "under the statutory language, you do not even get to Section 954(b)(4) unless the income in question would otherwise be Subpart F foreign base company income or insurance income, so income excluded from Section 951A 'by reason of' Section 954(b)(4) cannot be read to cover any other income."

Not only does Treasury's reading go beyond the clear terms of the statute in this regard, Treasury went further to create a taxpayer election where one does not exist in the statute. Tax elections always serve to benefit the taxpayer since the taxpayer will only elect when it is in its interest to do so (Field, 2010, pp. 21, 30-31). In this situation, the election is extremely taxpayer friendly, since some taxpayers with income subject to high foreign tax rates would prefer to follow the statute and report the GILTI inclusion along with the related foreign tax credits, while other taxpayers would prefer to make the election in the regulations and exclude the income from GILTI. Neither the text nor the legislative history justifies this result..$^{36}$

${ }^{35}$ Proposed GILTI Regulations, Preamble.

${ }^{36}$ In the Preamble, Treasury echoed taxpayer arguments that the GILTI high tax exclusion election comports with legislative history. S. Comm. on the Budget, Committee Recommendations as Submitted to the Committee on the Budget Pursuant to H. Con. Res. 71, S. Print No. 115-20, at 371 (2017). It is a basic tenet of statutory interpretation that clear text trumps legislative history. This is even more so the case when the legislative history is ambiguous at best. The legislative history invoked by Treasury states that items of income excluded from GILTI "include income subject to high levels of foreign tax." This statement likely references the category of income excluded by means of Section 954(b)(4) rather than contemplates a broad high-tax exclusion from GILTI. Moreover, nothing in the legislative history refers to electivity, which as noted above is far better for taxpayers than a mandatory exclusion of high taxed income from GILTI. Treasury itself recently stated in the Preamble to the final foreign tax credit regulations that Congress intended the expense allocation rules of the Code to apply to GILTI income. Guidance Related to the Foreign Tax Credit, 84 Fed. Reg. 69022 (December 17, 2019) (to be codified at 26 C.F.R. pt. 1). The principal effect of the high-tax exclusion is to avoid the adverse consequences to taxpayers of such expense allocation. It is impossible to reconcile Treasury's acknowledgment of Congress' intent to require expense allocation with Treasury's claim that the high-tax exclusion is consistent with Congressional intent. In addition, it is hard to imagine that Congress intended that foreign income that is subject to a foreign tax rate of 18.9 percent or above is eligible for the high-tax exemption and, therefore, exempt from expense allocation and any additional U.S. tax but that foreign income subject to a foreign tax rate below 18.9 percent is subject to expense allocation and, therefore, to a total U.S. and foreign tax in excess of 21 percent. Finally, some may point to the title of the section itself, "Global Intangible Low-Taxed Income," as evidence of congressional intent to only tax income subject to a low tax rate abroad. A heading cannot limit the plain meaning of the text and "has no power to give what the statute takes away." Trainmen $v$. Baltimore \& Ohio R.R., 331 U.S. 519, 529 (1947); Hawaii v. Office of Hawaiian Affairs, 556 U.S. 163, 175 (2009). Even if we take an unorthodox view that the title of a statute may trump its operative text, the GILTI acronym itself is a misnomer in other respects. Although the title refers to intangible income, the statute applies the minimum tax to income from both tangible and intangible assets. And, of course, the statute does not contain the term "election." Moreover, this argument assumes its conclusion in that the "low-taxed income" term could accommodate the expense allocation regime. The "income" portion of the phrase could be understood to represent true income net of properly allocated expenses. 


\section{b. THE CALCULATION OF THE EXEMPT RETURN IN GILTI}

Although the high-tax exception to GILTI is perhaps the most egregious example of Treasury making a gift to taxpayers, in derogation of statutory language, the regulations implementing the international regulations contain other examples.

In determining GILTI, the statute allows the taxpayer to exclude a deemed 10 percent return on tangible assets held abroad, as measured by tax basis. This exclusion, however, is reduced by the interest expense of the controlled foreign corporation. The more interest expense allocated to the deemed return, the lower the net deemed return and the greater the GILTI liability. Taxpayers, thus, wish to reduce the amount of interest allocated under the statute. Treasury has contravened the words of the statute by allowing the taxpayers to net all of their interest income against interest expense, rather than just the interest income received from related parties as is required by the statute (Rosenbloom, 2019, pp. 219, 290-291). This rule reduces the amount of interest expense they have to subtract from the exempt deemed return, and, in turn, decreases their GILTI liability. ${ }^{37}$

\section{Bank Relief from the BEAT}

In addition to the GILTI regime, the TCJA also created the new BEAT, which is a minimum tax regime that applies to certain domestic corporations that make deductible payments to foreign affiliates. Specifically, the BEAT requires that a U.S. corporation calculate its normal corporate tax liability at the 21 percent rate and then recalculate its liability by adding back in certain deductible payments to related parties, such as interest, royalties, and service payments, but at a 10 percent rate. If the latter recalculation exceeds the regular tax liability, the corporation owes the additional amount. ${ }^{38}$

The BEAT applies to foreign banks that lend money to their U.S. affiliates in order to meet American regulatory requirements, that is, before Treasury decided otherwise. Specifically, the clear statutory language of the BEAT encompasses the interest paid from the U.S. entities to their foreign parent companies. The new rules did not incorporate any kind of test that hinged on taxpayer intent to avoid taxes. Congress instead chose bright-line rules for this anti-abuse regime. Thus, the regulatory impetus behind the banks undergoing these transactions is irrelevant under the statute.

A few large foreign banks, including Credit Suisse and Barclays, reportedly lobbied Treasury for relief from the BEAT (Drucker and Tankersley, 2019). ${ }^{39}$ Treasury granted their request in the form of an exception for interest payments on debt issued by domestic "global systemically important banking organizations" where the debt is

\footnotetext{
${ }^{37}$ Guidance Related to Section 951A (Global Intangible Low-Taxed Income), 83 Fed. Reg. 51072 (October 10,2018 ) (to be codified at 26 C.F.R. pt. 1).

${ }^{38} 26$ U.S.C. $\$ 59 \mathrm{~A}(2018)$.

${ }^{39}$ Records from OIRA indicate that representatives of Credit Suisse continued to meet with Treasury officials about the BEAT regulations in September 2019, although the precise topic of the meeting was not disclosed. See Office of Information and Regulatory Affairs, EO 12866 Meeting 1545-BP36 (September 27, 2019), https://www.reginfo.gov/public/do/viewEO12866Meeting?viewRule=true\&rin=1545BP36\&meetingId=4533\&acronym=1545-TREAS/IRS.
} 
issued in response to requirements imposed by the Federal Reserve to minimize the risk of insolvency. ${ }^{40}$

Treasury, in later regulations and again in response to business interests, expanded the nonstatutory exception to apply to foreign and not just domestic institutions so long as they are subject to regulations similar to those issued by the Federal Reserve in the domestic context. Further, Treasury expanded the exemption for domestic institutions by allowing a buffer amount of excluded payments on interest on debt that exceeded the Federal Reserve's regulatory requirements. In doing so, Treasury officials responded to industry arguments that banks regularly issued securities above the regulatory requirements in order to accommodate changing balance sheets. ${ }^{41}$

Treasury justified these exceptions, which have no roots in statutory text, by the specific grant of authority in $\S 59 \mathrm{~A}(\mathrm{i})$, which, like many other Code provisions, directs Treasury to "prescribe such regulations or other guidance as may be necessary or appropriate to carry out the provisions of this section." Notably, this is distinct from more expansive grants of authority where Congress instructs Treasury to "carry out the purposes" of the section. ${ }^{42}$ This narrower grant of authority does not allow Treasury to contravene the requirements of the section by creating new exceptions to the minimum $\operatorname{tax}^{43}$

In later communications, a Treasury spokesperson would defend the bank carve-out, stating that, "[w]e were responsive to job creators" (Drucker and Tankersley, 2019). This statement does not obviate Treasury's duty to abide by the law and, instead, indicates that the notice and comment process is, in fact, being dominated by special interests who are undermining the rule of law.

Treasury's unilateral foreign bank relief will likely cost billions in revenue. Officials at the JCT put the revenue loss of exempting international banks at up to $\$ 50$ billion, which is nearly a third of the BEAT's projected revenue collection (Drucker and Tankersley, 2019). UBS, which lobbied for the regulatory changes, reported in its public filings that it expected to owe no BEAT liability due to regulations "that were considered helpful to foreign banks." ${ }^{\prime 4}$

${ }^{40}$ Base Erosion and Anti-Abuse Tax, 83 Fed. Reg. 65956 (December 21, 2018) (to be codified at 26 C.F.R. pt. 1). This is not the only example of special interest influence on the BEAT regulations. Treasury initially issued a rule that would have disallowed a complex currency transaction designed to circumvent the BEAT. It later withdrew the rule after objections from The Organization for International Investment, which represents foreign multinational corporations Nestle and LyondellBassell (Drucker and Tankersley, 2019).

${ }^{41}$ Preamble, Base Erosion and Anti-Abuse Tax, 83 Fed. Reg. 65956 (December 21, 2018) (to be codified at 26 C.F.R. pt. 1).

${ }^{42}$ See, for example, 26 U.S.C. $1298(\mathrm{~g})$.

${ }^{43}$ Moreover, even if a court were to construe this grant of authority to encompass purpose, the purpose of Section 59A appears to be to limit earnings stripping through an override of the arm's length principle. If Congress had wished to allow non-tax-motivated transactions to escape taxation, it could have simply deferred to the transfer pricing regime. Additionally, the five examples of appropriate regulations set forth in the specific grant of authority are aimed at preventing taxpayer avoidance of the statute. The interpretive principle of ejusdem generis would suggest that Congress envisioned the Treasury Regulations under BEAT to be in this ilk. Treasury has instead issued guidance aimed at abetting taxpayer avoidance.

${ }^{44}$ UBS Group AG, Report of Foreign Private Issuer (Form 6-K) (January 21, 2020). 


\section{Examples of Treasury Overreach from the 199A Regulations}

Section 199A is a new tax deduction for passthrough entities and sole proprietors. It attempted to appease noncorporate business interests that did not receive the benefit of the reduced corporate rate. The provision contains guardrails to narrow its scope, the efficacy of which was widely questioned prior to the enactment of the TCJA (Kamin et al., 2017). The scope of these guardrails has been the subject of intense lobbying in the regulatory process, with Treasury adopting lenient stances in the face of such pressure (Oei and Osofsky, 2019). Overwhelmingly, the comments received in both the pre- and formal notice period were from industry or business interests rather than those representing the public interest. ${ }^{45}$

Section 199A provides up to a 20 percent deduction on "qualified business income." The deduction is denied for taxpayers with income above certain amounts if the business is providing services within certain categories (health, law, consulting, and financial, among others). In addition to these specified services, the statute also denies the deduction to a catch-all category of trade or businesses whose principal asset is the "reputation or skill" of the owners or employees. This catch-all clause, as written, should have significantly narrowed the application of the 199A deduction.

The final 199A regulations, however, come close to reading the catch-all clause out of the statute. Under the regulations, the clause only applies to fact patterns in which an individual or pass-through entity is engaged in the trade or business of receiving income from endorsements, the licensing of an individual's likeness or features, and appearance fees. The regulations, thus, essentially strike "skill" from the catch-all clause by focusing only on narrow circumstances that involve reputation.

The regulations go further to also grant the deduction if reputation is combined with skill. For instance, the regulations contain an example of a well-known chef who receives profits from restaurants as well as a fee for endorsing cookware. According to the regulations, the restaurant income receives the deduction, whereas the endorsement fee does not. ${ }^{46}$ Here, the chef remains entitled to the deduction for the restaurant income presumably because the chef is generating returns in the restaurant by mixing labor with reputation (Kamin, 2018). But this result is in contravention of the statute, which limits the deduction if the principal asset of the business is attributable to reputation or skill. ${ }^{47}$

${ }^{45}$ For instance, of 337 comments received in the formal notice period, Oei and Osofsky counted only six that represented the public interest (Oei and Osofsky, 2019, p. 36). See also Wallace (2017, pp. 179, 182) (finding private interests dominating the tax notice and comment period).

${ }^{46} 26$ C.F.R. $\S 1.199 \mathrm{~A}-5(\mathrm{~b})(3)(\mathrm{xv})$.

${ }^{47}$ In the preamble to the regulations, Treasury and the IRS justified this narrow interpretation based on the concern that a broad interpretation would result in "substantial uncertainty" for taxpayers and the IRS. A broad reading, under their view, would also have the potential to exclude all service businesses, in contravention of Congressional intent. This argument overreaches because the statute contains a qualifier such that the "principal asset" must be reputation or skill, thus, on its own terms, limiting the reach of the catch-all to certain types of service businesses. Although there is an administrative challenge to enforcing the statute as written, Treasury and the IRS have no discretion to abandon its clear language simply because the fact-based inquiry creates uncertainty to the taxpayers. Indeed, one administrable option would have been to interpret the owner's portion of reputation and skill by formula, that is, deeming a normal rate of return of $\mathrm{x}$ percent to the business with any excess being deemed to be derived from reputation and skill. Lily Batchelder (@ lilybatch), Twitter (August 8, 2018, 11:11 Am), https://twitter.com/lilybatch/status/1027210665788940293. 
Rather than upholding Congressional intent, this regulation undermines it by providing high-income service providers a deduction for which they should have been ineligible under the statute. This contravenes the structure of Section 199A, which attempts to draw a distinction between businesses primarily based on reputation and skill (including the specifically enumerated ones) and other businesses.

Other examples of Treasury stretching the statute to accommodate lobbying interests include its implementation of the definition of "brokerage services," which is listed in the statute as one of the industries disfavored under $\S 199 \mathrm{~A}$. The regulations carve out real estate brokers and insurance brokers from that term. ${ }^{48}$ Similarly, the regulations allow banks to qualify for $\S 199 \mathrm{~A}$ by excluding deposits and making loans from the definition of "financial services," which is another disfavored industry under the statute. In the Preamble, Treasury noted that this carve-out was in response to comments from taxpayers. ${ }^{49}$

\section{Examples of Treasury Overreach from the Opportunity Zone Regulations}

The TCJA's opportunity zone provision lets investors defer capital gains on assets by "rolling" them into funds that make real estate investments in "opportunity zones" or areas that have been designated as low income. ${ }^{50}$ If investors meet certain requirements, they can receive tax-free basis on their assets and even permanently exempt the gains under certain circumstances.

In order to further the provision's purpose of revitalizing disadvantaged areas, the statute defines the scope of permissible investments that a fund can make to qualify for the tax advantages. Among the permissible investments are purchases of "qualified opportunity zone property." 51 The statute cross-references Section 179 to require that such purchases be from unrelated parties. The regulations, however, extend the definition to leases from related parties. ${ }^{52}$

The statute also requires that these investments either coincide with the "original use of the property" or "substantially improve" the property, which is defined as "additions to basis." ${ }^{53}$ Basis is a tax concept that is defined as the original cost of property adjusted upward by capital expenditures made to the property and downward by depreciation deductions. ${ }^{54}$ Capital expenditures, in turn, are defined as "permanent improvements or betterments made to increase the value of any property." ${ }^{55}$ The IRS has, in the residence context, illustrated this concept with the following examples: a home addition, replacing an entire roof, driveway paving, installing central air conditioning, or rewiring your home.

\footnotetext{
4826 C.F.R. § 1.199A-5(b)(2)(x).

4926 C.F.R. $\S 1.199$ A-5(b)(2)(ix).

5026 U.S.C. $\S 1400 Z-2$.

5126 U.S.C. $\S 1400 Z-2(d)(2)(D)(i)$.

52 Treas. Reg. § 1.1400Z2(d)-(2)(c).

5326 U.S.C. $\$ 1400 Z-2(d)(2)(D)(i i)$.

${ }^{54} \mathrm{Id}$. at $\S 1016$.

${ }^{55} I d$. at $\S 263$ and regulations thereunder.
} 
Flouting the common understanding of basis and "permanent improvements," including its prior interpretations of the concept, in the opportunity zone context Treasury has expanded additions to basis beyond the statute to purchases of tangible property such as linens, mattresses, furniture, and gym equipment. ${ }^{56}$

Treasury went even further in creating a nonstatutory exception for vacant land. Contrary to the text of the statute, as well as the intent of Congress to improve low-income communities, vacant land need not satisfy the original use or substantial improvement test so long as the land is used in a trade or business or there is an intention to improve the land within 30 months of purchase. ${ }^{57}$ Treasury justified this statutory departure on policy grounds.

\section{POSSIBLE PATHS FORWARD}

What does the future hold for the tax legislative and regulatory process in an era of reconciliation? Are there possible improvements we can make to reduce its more pathological tendencies? I explore some of these questions below.

\section{A. The Legislative Process}

Going forward, the sunsets of the 2017 bill will lead to more budgetary gamesmanship. Party polarization will also continue to put immense pressure on the estimates and the estimators. Although the budget rules ultimately held during the 2017 process, budget norms were destabilized, indicating points of vulnerability.

One possible path to improve the reconciliation process would be to better align the Byrd rule with aims of deficit reduction. Sunset provisions and other budget gimmicks allow the circumvention of out-year deficit impact while still meeting the letter of the rule (Kysar, 2011, pp. 1007, 1028). Of particular importance is shoring up the budget baseline to ensure that parties do not toggle between one of current policy and one of current law in order to reenact unpaid-for temporary legislation (Kamin and Kysar, 2017; better.gop, 2016). A new baseline rule could assume provisions are temporary unless they were enacted for budgetary reasons, that is, unless they were enacted through a reconciliation bill (Kysar, 2020b, p. 86).

Moreover, the Byrd rule's prohibition on provisions that add to the deficit in out-years only works if the budget window is relatively short (Aprill and Hemel, 2018). In prior work, I have recommended different budget windows for varying purposes (Kysar, 2020b, pp. 77-78). For budget rule purposes, for instance, a shorter budget window overcomes the practical difficulties of implementing longer estimates and the gaming opportunities presented by such a window. Estimators, however, could make use of longer-term projections outside of the official scores in order to glean a better picture of the long-term fiscal health of the nation (Kysar, 2020b, pp. 77-78).

\footnotetext{
${ }_{56}$ Treas. Reg. § 1.1400Z2(d)-2(b)(4)(iii)(D)(1).

${ }^{57}$ Treas. Reg. § 1.1400Z2(d)-2(b)(4)(iv)(B)-(C).
} 
The instability of both the budget baseline and budget window can be traced to the fact that both of these important features of reconciliation can be altered by a simple majority vote, otherwise circumventing the supermajority rules of the Senate, by enacting such change in the budget resolution. Another possible avenue is to change Senate procedure involving the budget resolution, requiring certain aspects of it to be subject to normal supermajority rules. This would go a long way to stabilizing the budget rules.

Additional concerns stemming out of the 2017 process include the invocation of the Byrd rule for measures that would effectuate fiscal discipline, for instance, the aforementioned trigger mechanisms that purportedly ran afoul of the Byrd rule's prohibition on provisions with no budgetary impact. Additionally, the parliamentarian's rulings with regard to subject matter limitations of the Byrd rule, at times, appear to be haphazard (Aprill and Hemel, 2018). Some of the frustration over these rulings can be traced to their nontransparency, which is justified by the parliamentarian's need for insulation from politics. What we know about the parliamentarian's rulings or reasoning surrounding them often only occurs from staff or senators who choose to share. Aprill and Hemel (2018) have recommended that Budget Committee staffers publish short summaries of how the senate parliamentarian ruled and the office's rationales in applying the Byrd rule. This solution would balance political insulation with public accountability.

More generally, the use of reconciliation for tax legislation itself poses risk. The partisan and party-led process has the tendency to produce unstable legislation that lacks the expertise of the tax institutions. Reconciliation's quick time frame also increases the chance for mistakes and ambiguities. As Treasury steps in to make sense of the legislation, this leaves room for private interests to capture the regulatory process. All of these dynamics occurred during the TCJA process.

These features of reconciliation are particularly problematic when it comes to complex tax reform, which demands considered expertise to design and stability to effectuate its goals. Resurrecting an idea from the 1980 s, reconciliation could be limited to changing tax rates rather than the tax base (Federal Bar Association, 1988, pp. 1581, 1583). A rates-only rule for reconciliation, however, may be overly broad since minor substantive tax legislation can withstand the limitations of the process. Moreover, once reconciliation becomes the norm for enacting tax legislation, as we have seen over the past two decades, it is difficult to put the genie back into the bottle.

Reconciliation's capture of the tax legislative process, however, may be short-lived. Another major takeaway from the past two decades of tax lawmaking is that reconciliation has been functioning as a release valve for the filibuster (Kysar, 2020b, p. 63). In many ways, it is allowing the filibuster to continue because there is less of a need to invoke the nuclear option in one of the most controversial and important policy areas. Since the judicial filibuster has steadily eroded over the years, a new majority in the Senate, however, may very well end the legislative filibuster, making minority rights 
in the Senate a bygone era. ${ }^{58}$ If this occurs, the role of the budget process will greatly diminish. No majority will need to use reconciliation anymore to pass legislation across party lines, so the Byrd rule, as well as statutory pay-go rules, will have no teeth.

What would tax legislation look like without the strictures of the budget process? There may, for instance, be no need for sunsets and other tax provisions inspired by the budget rules. The overall cost of legislation may, however, reach new heights, although it is certainly in dispute how successful reconciliation has been at achieving fiscal discipline (Aprill and Hemel, 2018). One potential mechanism to deal with the loss of the budget rules' enforcement mechanism, either through the fall of the legislative filibuster or the choice not to use reconciliation for complex tax legislation, could be to bake budget goals into the statute, as opposed to enforcing them through process rules (Kysar, 2019, pp. 809, 867). Tax laws, for instance, could be pegged to a revenue goal. We have seen some experimentation with these types of mechanisms or "triggers" during the TCJA process..$^{59}$

Congress would find budgetary targets built into the substance of the law less easy to evade than the budget rules. ${ }^{60}$ For instance, in the early 1980 s, proposed legislation would have limited the amount of revenue lost to tax expenditures to no more than 30 percent of the net revenues collected in the fiscal year. ${ }^{61}$ Although this was enforced through a procedural rule, one could imagine that a budget constraint such as this could be embedded within the substantive statute. If, for instance, the prior year's revenues could dictate the total amount of tax expenditures available, then the tax expenditures could be automatically granted if the benchmarks were met (Kysar, 2019, p. 864).

Reconstituting the policy role of the tax institutions is another important goal for improving the legislative process. One possible consequence of the fall of reconciliation might possibly be to restore some primacy to the tax committees and the JCT. Reconciliation shifted power away from these committees into the hands of party leaders and the budget committees, making policy and technical expertise of the tax committees and other tax institutions less important. If the use of reconciliation falls

\footnotetext{
${ }^{58}$ In 2017, Senate Republicans deployed the nuclear option to remove the filibuster for Supreme Court nominees. Flegenheimer, Matt, "Senate Republicans Deploy 'Nuclear Option’ to Clear Path for Gorsuch," New York Times, April 6, 2017, https:/www.nytimes.com/2017/04/06/us/politics/neil-gorsuch-supremecourtsenate.html. Senate Democrats have increasingly threatened doing the same for the legislative filibuster should they come to power.

${ }^{59}$ Senate deficit hawks proposed to reverse the tax cuts in the TCJA if the law's deficit impact turned out to be worse than advertised. Pramuk, Jacob, "Senate GOP Rushes to Change Tax Bill as Setback Hits Hours before Vote," CNBC (November 30, 2017), https://www.cnbc.com/2017/11/30/parliamentariansays-revenue-trigger-in-gop-tax-plan-will-not-work-under-rules-of-senate.html. Ironically, the senate parliamentarian ruled that the trigger did not meet the Byrd rule requirement of having a budgetary impact (Aprill and Hemel, 2018).

${ }^{60}$ These mechanisms could extend far beyond tax. For instance, in the Social Security context, benefits and taxes could be automatically adjusted if the system is projected to become insolvent (Kamin, 2014).

${ }^{61}$ Tax Expenditure Limitation and Control Act of 1981, S. 193, 97th Cong.
} 
away with the filibuster, then the tax institutions could once again regain prominence. Although the JCT would still produce revenue estimates on tax bills, being freed from providing advice on various Byrd rule challenges may allow the committee to return to more policy analysis. Reduced emphasis on outlining the parameters of tax legislation in the initial budget resolution may also help to restore Treasury and the tax-writing committees to their agenda-setting role. That being said, if supermajority requirements in the Senate are removed, the promotion of party agenda without the need to win over the minority through vote trading may mean the continued sacrificing of tax policy goals for party goals.

\section{B. The Regulatory Process}

The implementation of the TCJA illustrates grave problems with the regulatory process. It is tilted toward the well-resourced, who can influence Treasury's interpretation from early stages. Moreover, existing standing doctrine ensures that there is no way to hold Treasury accountable when it goes beyond the statute in its implementation. Congress could do much more to improve the regulatory process and give Treasury the tools it needs to stave off industry influence, which I outline below. A cynic may counter that Congress prefers the current state of affairs precisely because it benefits business interests and, thus, may be unwilling to conduct agency oversight. Still, one can hope that although congressional members may be tempted to abet certain transfers of resources to industry, overall, they aim for transparency and good government. Implementing these principles ensures that individual members do not defect from that common, larger goal.

Statutory Fixes and Power of the Purse. When possible, Congress could rescind Treasury's misguided implementation of the law through clarification of the statute. The House and Senate could also pass a joint disapproval resolution striking down a particular regulation or set of regulations under the Congressional Review Act, so long as certain procedural requirements are met. Finally, Congress has, in the past, put in an appropriations bill a provision that no money can be spent on implementing a specific regulatory provision with which it disagrees.

Empower Federal Officials. One possible solution to the lack of standing to challenge Treasury and the IRS actions benefiting certain taxpayers would be a Congressional grant of power to an ombudsman, inspector general, or other federal official to bring suit against Treasury and the IRS for regulatory decisions that contravene statutory authority. ${ }^{62}$ Congress has taken such an approach in other circumstances. ${ }^{63}$ Since the

${ }^{62}$ See Graetz, Schenk, and Alstott (2018) introducing such an approach as a possibility; see also Sugin (2016) (suggesting an ombudsman, such as the Taxpayer Advocate, to monitor constitutional issues arising from tax regulation).

${ }^{63}$ See, for example, $\S 301$ of the Voting Rights Act Amendments of 1975, 42 U.S.C. § 1973bb; Title VII of the Civil Rights Act of 1964, $\S \S 706-07$, as amended, 42 U.S.C. $\S \S 2000$ e- 5 to 2000 e- 6 . Another possible model is the cause of action given to the comptroller general in the event of an illegal impoundment. Impoundment Control Act of 1974, 2 U.S.C. § 687. 
United States has standing to bring criminal suits, it has been suggested that Article III standing does not require injury in fact and suits by appointed federal officials may meet the standing hurdles (Hartnett, 1999, pp. 2239, 2255-2258). Nonetheless, the constitutionality of this approach is unclear.

Improve the Regulatory Process. The failures of implementing the TCJA indicate a need to improve transparency in the rulemaking process. First, Congress could mandate that Treasury publicize any written comments it receives during the prenotice period as well as provide a record of in-person contacts with private parties if they pertain to the rulemaking process no matter if they occur pre or post notice (Oei and Osofsky, 2019). ${ }^{64}$ Second, Congress could require Treasury to convene advisory councils that represent the public interest to assist Treasury in the rulemaking process. ${ }^{65}$ Relatedly, Congress could also expand the Taxpayer Advocate Service to have a more direct role in the formation of regulations (Book, 2012, pp. 517, 568-583).

Making the Costs Transparent. One troubling aspect of regulatory giveaways to taxpayers is that they are never paid for. To the extent a regulation contravenes the statute, the cost of the rule will not be factored into the original JCT score of the legislation. When Treasury promulgates the regulation, however, it then becomes law. For purposes of enforcing the budget rules, the new nonstatutory interpretation will be subsumed within the $\mathrm{CBO}$ baseline, which is primarily constructed from current law. This means that the cost of the taxpayer-friendly regulation will escape the budget process entirely. ${ }^{66}$ Congress could task the JCT with evaluating all Treasury and IRS tax guidance and producing a revenue estimate where that guidance is deemed significant. Congress could specify a threshold, such that guidance is deemed significant when it has an effect of greater than, say, $\$ 100$ million on receipts or spending in either direction relative to the baseline. ${ }^{67}$

Require Better Public Disclosure of Tax Liability. U.S. securities laws require detailed disclosure of the components of income tax expense that exceed 5 percent of their income before tax, multiplied by the applicable statutory tax rate. ${ }^{6}$ Many corporations, however, seem to be circumventing this rule by grouping GILTI liability with other expenses and benefits. ${ }^{69}$ Congress should use its oversight authority to ensure the Securities and

\footnotetext{
${ }^{64}$ At least one agency has adopted a policy that mandates that ex parte communications about pending rulemaking be documented in writing in order to ensure transparency. McCoy, Patricia A., Comment of Financial Regulation and Consumer Protection Scholars and Former Regulators on Docket No. CFPB-2018-000933 (June 7, 2018), available at https://www.regulations.gov/document?D=CFPB-2018-0009-0121 (discussing the Consumer Financial Protection Bureau's (CFPB's) rulemaking process).

${ }^{65}$ The CFPB has done this voluntarily. Id.

${ }^{66}$ Kamin and Kysar, 2017 (discussing the need for consistent baselines in ensuring the budget process captures the cost of legislation).

${ }^{67}$ The $\$ 100$ million threshold would match the threshold for "economically significant" regulatory action for purposes of OIRA review.

6817 C.F.R. $\$ 210.4-08(h)(1)$ (2018).

${ }^{69}$ Eavis, Peter, "Why the Impact of the Trump Taxes Remains Partly Hidden," New York Times (December 30, 2019), https://www.nytimes.com/2019/12/30/business/corporate-tax-cuts-impact.html.
} 
Exchange Commission is enforcing this provision adequately. Alternatively, Congress could make a statutory rule requiring disclosure of tax liability under the TCJA's base erosion provisions. This would allow scrutiny of whether the new regime is working as intended and whether Treasury's implementation of it is overly generous.

Delegate Less. Treasury's implementation of the TCJA should serve as a cautionary tale to Congress in rushing complex tax legislation through the reconciliation process. The interpretive challenges underscore the necessity for Congress to slow down the process and legislate with more precision. It also serves to highlight the dangers in delegating broadly to Treasury without at least tightening the regulatory process. The lack of representation of the public interest, transparency, and budget accountability, along with the inability for taxpayers to challenge improper revenue-losing regulations, means that the process will inevitably be weighted toward special interests. This exacerbates already existing problems with the tax legislative process. These insights call into question recent suggestions that Congress should make greater use of delegation in the tax context, for instance, by delegating rate changes to Treasury or an independent body such as the Federal Reserve (Hines and Logue, 2015, p. 235). Rather than delegate broadly to Treasury, the TCJA regulatory process suggests that Congress should reassert its primary role over tax lawmaking.

Less delegation would require more precise statutory drafting. ${ }^{70}$ Although this would seem to implicate the classic rules versus standards debate, weighing costs of drafting against costs of application (Kaplow, 1992, pp. 557-629), Congress can still draft legislation that is adaptive to circumstances while being precise in its contours. Moreover, my recommendations do not forestall all delegation, of course, but it is vitally important that Congress guards its taxing and spending powers carefully in order to maintain ways to rein in the executive. In deciding how much to delegate to Treasury, Congress should recognize that delegation carries particular risks given the pathologies of the regulatory process in the tax context. In particular, Congress should guard its prerogatives over major policy decisions and should draft tax legislation carefully in order to avoid inadvertent delegation. These suggestions comport with the constitutional framework of entrusting Congress with special duties over taxation. ${ }^{71}$

\section{CONCLUSION}

The TCJA marks the culmination of a new era of tax lawmaking that has been two decades in the making. Reconciliation has become the preferred vehicle of choice for both simple and complex tax legislation, although it is particularly ill-suited for the latter given the partisan and truncated manner in which it operates. These features produce precarious and flawed legislation, which is particularly problematic for achieving true tax reform. Moreover, as Treasury must step in to fix and interpret the legislation, it

\footnotetext{
${ }^{70}$ Note that more precise statutory drafting would not solve the problem of Treasury interpreting against clear statutory language, which is a democratic concern of greater proportions.

${ }^{71}$ Kysar (2013, p. 1) tracing the history of the Origination Clause.
} 
succumbs to business interests due to deficiencies in the regulatory process and litigation dynamics. The new era, however, may be short-lived as the Senate seems poised to eliminate the legislative filibuster in the near future, making reconciliation obsolete. This will certainly create new challenges for tax legislation. Until then, there are ways to improve upon the legislative and regulatory process in its current incarnation.

Since the birth of the nation, taxation and democracy have been closely intertwined. The manner in which tax laws are made and implemented should aim to preserve, not sever that connection. Congress should strive to improve upon budget rules so that they better effectuate their goals without supplanting traditional tax policy aims. Congress should also give Treasury the tools it needs to weigh the public interest against private ones. Most importantly, Congress should take ownership over its duty to the polity in providing clear, comprehensive, and reasoned tax legislation, without overly delegating to an overburdened and unelected agency.

\section{ACKNOWLEDGMENTS}

Portions of this paper draw upon testimony before the House Ways and Means Committee. Rebecca Kysar, Testimony before the U.S. House of Representatives Ways and Means Committee, TCJA's Business Tax Provisions: Design Flaws and Undemocratic Implementation (February 11, 2020). I thank William Gentry for superb comments, Christina John for excellent research assistance, and Joe Rosenberg for inviting me to present this paper at the National Tax Association's Spring Symposium.

\section{DISCLOSURE}

The author has no financial arrangements that might give rise to a conflict of interest with respect to the research reported in this paper.

\section{REFERENCES}

Aprill, Ellen, and Daniel Hemel, 2018. "The Tax Legislative Process: A Byrd's Eye View." Law and Contemporary Problems 81 (2).

Auerbach, Alan J., 2017. "Demystifying the Destination-Based Cash-Flow Tax." Brookings Papers on Economic Activity 48 (2), 409-432, https://www.brookings.edu/wp-content/uploads/2018/02/ auerbachtextfa17bpea.pdf.

Batchelder, Lily, and David Kamin, 2019. “Taxing the Rich: Issues and Options.” Working Paper, https://papers.ssrn.com/sol3/papers.cfm?abstract_id=3452274.

Bellafiore, Robert, 2018. "Tax Expenditures Before and After the Tax Cuts and Jobs Act." Tax Foundation, Washington, DC, https://taxfoundation.org/tax-expenditures-pre-post-tcja/.

better.gop, 2016. "A Better Way: Our Vision for a Confident America," https://www.novoco.com/ sites/default/files/atoms/files/ryan_a_better_way_policy_paper_062416.pdf 
Birnbaum, Jeffrey H. (introduction by Alan Murray), 1988. Showdown at Gucci Gulch: Lawmakers, Lobbyists, and the Unlikely Triumph of Tax Reform. Vintage Contemporaries, New York, NY.

Book, Leslie, 2012. "A New Paradigm for IRS Guidance: Ensuring Input and Enhancing Participation.” Florida Tax Review 12 (7).

Byrd, Robert, 2001. "Remarks of Sen. Robert Byrd.” Congressional Record 147 (49).

Clausing, Kimberly A., 2020a. "Fixing Five Flaws of the Tax Cuts and Jobs Act.” Working Paper, https://papers.ssrn.com/sol3/papers.cfm?abstract_id=3397387.

Clausing, Kimberly A., 2020b. "Profit Shifting Before and After the Tax Cuts and Jobs Act." Working Paper, https://papers.ssrn.com/sol3/papers.cfm?abstract_id=3274827.

Clifton, Daniel, 2017. "How Tax Reform Will Play Out This Fall." Barron's, https://www.barrons.com/articles/how-tax-reform-will-play-out-this-fall-1507057230.

Congressional Budget Office, 2020a. "Recent Changes in CBO's Projections of Corporate Income Tax Revenues.” Congressional Budget Office, Washington, DC, https://www.cbo.gov/ publication/56121.

Congressional Budget Office, 2020b. “The Budget and Economic Outlook: 2020-2030.” Congressional Budget Office, Washington, DC, HTTPs:/www.CBO.gOv/system/FILEs/2020-01/56020CBO-OUTLOOK.PDF.

Drucker, Jesse, and Jim Tankersley, 2019, "How Big Companies Won New Tax Breaks from the Trump Administration.” New York Times, https:/www.nytimes.com/2019/12/30/business/ trump-tax-cuts-beat-gilti.html.

Federal Bar Association, 1988. "The Condition of the Tax Legislative Process.” Tax Notes 39.

Field, Heather M., 2010. "Choosing Tax: Explicit Elections as an Element of Design in the Federal Income Tax System.” Harvard Journal on Legislation 47 (1).

Graetz, Michael J., 1995. "Paint-by-Numbers Tax Lawmaking." Columbia Law Review 95 (3).

Graetz, Michael J., Deborah Schenk, and Anne Alstott, 2018. Federal Income Taxation: Principles and Policies, Eagan, MN.

Handler, Harold R., 1987. "Budget Reconciliation and the Tax Law: Legislative History or Legislative Hysteria?” Tax Notes 37.

Hanlon, Seth, and Alex Rowell, 2017. "The Senate Tax Bill Is Even More Costly under Current Policy Assumptions.” Center for American Progress, Washington, DC, https://www.americanprogress.org/issues/economy/news/ 2017/12/13/444103/senate-tax-bill-even-costly-currentpolicy-assumptions.

Hartnett, Edward A., 1999. "The Standing of the United States: How Criminal Prosecutions Show That Standing Doctrine Is Looking for Answers in All the Wrong Places. Michigan Law Review 97.

Hemel, Daniel, 2017. “The President's Power to Tax.” Cornell Law Review 102. 
Hines, James R. Jr., and Kyle D. Logue, 2015. “Delegating Tax.” Michigan Law Review 114 (2).

Kamin, David, 2014. "In Good Times and Bad: Designing Legislation that Responds to Fiscal Uncertainty." Hutchins Center on Fiscal \& Monetary Policy Working Paper No. 7. Brookings Institution, Washington, DC.

Kamin, David, 2015. "Basing Budget Baselines.” William \& Mary Law Review 57 (1).

Kamin, David, 2018. “'Reputation or Skill' in the New Pass-Through Regulations.” Medium, https://medium.com/whatever-source-derived/reputation-or-skill-in-the-new-pass-throughregulations-efac160f4fbe\#_ftn1.

Kamin, David, Reuven S. Avi-Yonah, Lily L. Batchelder, J. Clifton Fleming, et al., 2017. "The Games They Will Play: Tax Games, Roadblocks, and Glitches under the House and Senate Tax Bills.” Working Paper, https://papers.ssrn.com/sol3/papers.cfm?abstract_id=3084187.

Kamin, David, and Rebecca M. Kysar, 2017. "Temporary Tax Laws and the Budget Baseline." Tax Notes 157 (1).

Kaplow, Louis, 1992. "Rules versus Standards: An Economic Analysis.” Duke Law Journal 42.

Kapur, Sahil, 2017. "GOP Push for 20-Year Tax Cut Grows as Ryan Seeks Permanent Fix." Bloomberg, https://www.bloomberg.com/news/articles/2017-06-24/gop-push-for-20-year-taxcut-grows-as-ryan-seeks-permanent-fix.

Kysar, Rebecca M., 2011. “Lasting Legislation.” University of Pennsylvania Law Review 159 (4).

Kysar, Rebecca M., 2013a. "On the Constitutionality of Tax Treaties." Yale Journal of International Law 38 (1/2).

Kysar, Rebecca M., 2013b. "Reconciling Congress to Tax Reform.” Notre Dame Law Review 88 (5).

Kysar, Rebecca M., 2018a. "Judging the New International Tax Regime.” Testimony, April 24. U.S. Senate Committee on Finance, Washington, DC.

Kysar, Rebecca M., 2018b. "Taxes and the Eroding Budget Process.” Law and Contemporary Problems 81.

Kysar, Rebecca M., 2019. “Dynamic Legislation.” University of Pennsylvania Law Review 167 (4).

Kysar, Rebecca M., forthcoming 2021. "Interpreting by the Rules.” Texas Law Review 99.

Leibenluft, Jacob, and Chye-Ching Huang, 2017. “GOP Process Designed to Obscure Tax Plan's Effects." Center on Budget and Policy Priorities, Washington, DC, https://www.cbpp.org/research/ federal-tax/gop-process-designed-to-obscuretax-plans-effects.

McGinnis, John O., and Michael B. Rappaport, 2005. "The Judicial Filibuster, the Median Senator, and the Countermajoritarian Difficulty." Supreme Court Review 2005 (1).

Oei, Shu-Yi, and Leigh Osofsky, 2019. "Legislation and Comment: The Making of the § 199A Regulations.” Emory Law Journal 69 (2). 
Pomerleau, Kyle, 2017. "Economic and Budgetary Impact of Temporary Expensing." Tax Foundation, Washington, DC, https://taxfoundation.org/economic-budgetary-impact-temporaryexpensing/.

Rosenbloom, David, 2019. "Comments at the Symposium on 'The Future of the New International Tax Regime.” Fordham Journal of Corporate \& Financial Law 24 (2).

Shaviro, Daniel, 2018. "Evaluating the New US Pass-Through Rules.” British Tax Review 1.

Shay, Stephen E., 2019. "A GILTI High-Tax Exclusion Election Would Erode the U.S. Tax Base." Tax Notes 165.

Sugin, Linda, 2016. “Invisible Taxpayers.” Tax Law Review 69.

Sullivan, Martin A., 2018. "More GILTI Than You Thought.” Tax Notes 158.

Van de Water, Paul N., 2019. "Policymakers Shouldn't Repeal or Further Delay the 'Cadillac Tax."' Center on Budget and Policy Priorities, Washington, DC, https://www.cbpp.org/blog/ policymakers-shouldnt-repeal-or-further-delay-cadillac-tax.

Wallace, Clinton G., 2017. "Congressional Control of Tax Rulemaking.” Tax Law Review 71.

Yin, George K., 2006. "Is the Tax System beyond Reform?" University of Florida Law Review $58(5)$.

Zelenak, Lawrence, 2012. "Custom and the Rule of Law in the Administration of the Income Tax.” Duke Law Journal 62 (3). 